\title{
Perbandingan Laju Pertumbuhan Kappaphycus alvarezii yang Dipelihara pada Media Horinet dan Media Longnet
}

\author{
[Comparison of Growth Rates Of Kappaphycus alvarezii Maintained \\ on Horinet Media and Longnet Media] \\ Dita Pramesti Chayani $\mathbf{R}^{1}$, Ruslaini ${ }^{1 *}$, Ma'ruf Kasim ${ }^{2}$ \\ ${ }^{1}$ Budidaya Perairan, Fakultas Perikanan dan Ilmu Kelautan, Universitas Halu Oleo \\ ${ }^{2}$ Program Studi Manajemen Sumberdaya Perairan, Fakultas Perikanan dan Ilmu Kelautan, Universitas Halu Oleo \\ JL. HAE Mokodompit Kampus Bumi Tridharma Anduonohu Kendari, Indonesia 93232 \\ *Email korespondensi: ruslaini@uho.ac.id
}

\begin{abstract}
Abstrak
Rumput laut Kappaphycus alvarezii merupakan komoditas ekspor yang saat ini banyak dibudidayakan oleh masyarakat pesisir, namun dalam kegiatan budidayanya menghadapi permasalahan dalam hasil pertumbuhan produksi bibit yang diperoleh. Olehnya, Penelitian ini bertujuan untuk mengetahui perbandingan laju pertumbuhan $K$. alvarezii yang dipelihara dengan menggunakan media berbeda yaitu horinet dan longnet, di Perairan Pantai Lakeba, Kota Bau-Bau, Sulawesi Tenggara. Metode yang digunakan yaitu metode ikat dengan menggunakan media horinet dan media longnet. Parameter yang diamati adalah pertumbuhan mutlak dan laju pertumbuhan spesifik. Hasil penelitian menunjukkan bahwa laju pertumbuhan spesifik tiap minggu mengalami penurunan baik pada media horinet maupun longnet, nilai rata-rata diperoleh tertinggi pada pemeliharaan dalam media horinet $3,77 \%$ dan terendah pada longnet sebesar $3,30 \%$. Sedangkan pertumbuhan mutlak dalam setiap minggu rata-rata tertinggi diperoleh untuk media horinet $74,95 \mathrm{~g}$ dan terendah pada media longnet diperoleh 58,3 g. Parameter yang berpengaruh secara signifikan terhadap pertunbuhan mutlak dan laju pertumbuhan spesifik rumput laut $K$. alvarezii yang dipelihara pada media horinet dan longnet adalah kecepatan arus. Sedangkan parameter yang tidak berpengaruh secara signifikan adalah suhu, salinitas, $\mathrm{pH}$, fosfat, nitrat.
\end{abstract}

Kata Kunci: Kappaphycus alvarezii, Metode Horinet, Metode Longnet, Pertumbuhan, Laju Pertumbuhan Spesifik

\section{Abstract}

Kappaphycus alvarezii seaweed is an export commodity that is currently widely cultivated by coastal communities, but in its cultivation activities it experiences growth constraints which results in reduced production. Therefore, this study aims to determine the comparison of the growth rate of K. alvarezii maintained by using different media, namely horinet and longnet, in the waters of Lakeba Beach, Bau-Bau City, Southeast Sulawesi. The method used is the same method as the binding method using horinet media and longnet media. The parameters observed were absolute growth and specific growth. The results showed that the specific growth rate of each week decreased both on horinet and longnet media, the highest average value of maintenance on horinet media was $3.77 \%$ and the lowest was on longnet $3,30 \%$. While the highest absolute growth was obtained for horinet media $74.95 \mathrm{~g}$ and the lowest for longnet media $58.3 \mathrm{~g}$. The parameter which significantly affected the growth rate of $K$. alvarezii seaweed on horinet and longnet media was the current velocity. Meanwhile, the parameters that had no significant effect were temperature, salinity, $\mathrm{pH}$, phosphate and nitrate.

Keywords: Kappaphycus alvarezii, Horinet Method, Longnet Method, Growth, Spesific Growth

\section{PENDAHULUAN}

Rumput laut khususnya
Kappaphycus alvarezii merupakan
komoditas ekspor yang saat ini banyak
dibudidayakan oleh masyarakat pesisir.
Budidaya rumput laut itu memiliki nilai
ekonomis yang tinggi, selain karena
budidayanya yang sangat mudah serta tidak
memerlukan modal investasi yang besar.
Sebagai komoditas dalam hasil perikanan
yang menjadi sumber utama dalam penghasil
karagenan yaitu banyak sekali dimanfaatkan
baik dalam industri kosmetik, farmasi,

makanan dan industri lainnya seperti industri tekstil, pasta, pengalengan ikan, kertas dan fotografi (Utojo dkk., 2007). K. alvarezii banyak mengandung karagenan dengan tipe kappa. Bentuk tallusnya sangat bervariasi mulai dari yang paling sederhana sampai bentuk kompleks dengan warna hijau, hijau kuning, abu-abu atau merah (Nugroho \& Kusnandar, 2015).

Perkembangan metode budidaya rumput laut pada dasarnya terdapat tiga metode yang akan digunakan untuk membudidayakan rumput laut yaitu metode dasar, lepas dasar, dan terapung. Sejak tahun 
1985 di Indonesia dimulai kegiatan budidaya rumput laut $K$. alvarezii dengan menggunakan metode rakit apung dan berkembang lagi sejak tahun 1992 menjadi metode long line. Berkembangnya kegiatan budidaya rumput laut mempengaruhi teknik budidaya yang dari metode lepas dasar menjadi metode net bag (Susanto, 2005; Soenardjo, 2011) dan metode apung menjadi metode long line yang telah dimodifikasi (Yusup $d k k$., 2017). Salah satu faktor penting sebagai acuan keberhasilan dalam suatu kegiatan budidaya adalah penggunaan metode. Penggunaan metode harus disesuaikan berdasarkan jenis rumput laut dan kondisi perairan. Rumput laut dapat tumbuh dengan baik di daerah pantai terumbu karang (reef) (Wiratmaja $d k k$, 2011). Beberapa metode budidaya rumput laut yang telah banyak dikembangkan diantaranya metode lepas dasar, metode tali rawai dan metode rakit jaring apung. Metode jaring kantong apung hampir serupa dengan rakit jaring apung dalam metode pemeliharaannya, hanya saja terdapat perbedaan pada bagian spesifikasi bentuknya. Namun dari segi fungsional sama-sama melindungi bibit rumput laut dari hama maupun kotoran yang menempel (Kasim, $d k k l, .2016$ ).

Pertumbuhan rumput laut dipengaruhi oleh dua faktor yaitu faktor internal dan faktor eksternal. Faktor internal yang mempengaruhi pertumbuhan rumput laut yaitu spesies, bagian tallus dan umur, sedangkan faktor eksternal yaitu dipengaruhi oleh lingkungan, jarak tanaman, berat bibit awal, teknik penanaman dan metode budidaya (Saputra $d k k$., 2013). Adanya faktor-faktor yang mendukung dalam laju pertumbuhan rumput laut tersebut, yaitu dari teknik penanaman, alat yang akan digunakan serta metode budidaya adalah salah satu faktor penting yang harus dipilih secara tepat dalam budidaya. Kendala yang sering dihadapi oleh masyarakat pesisir dalam melakukan budidaya rumput laut yaitu serangan hama ikan maupun penyu, dimana faktor tersebut sangat intens pada daerahdaerah rumput laut dan menyebabkan masyarakat pesisir menjadi frustasi. Budidaya rumput laut sangat banyak yang melakukannya, akan tetapi serangan hama juga sangat banyak dan menyebabkan produksi rumput laut yang dihasilkan akan menurun. Masyarakat pesisir masih sangat kurang dalam memahami metode serta teknologi yang efektif maupun efisien serta penangan hama yang masih sangat kurang (Kasim, 2019). Masyarakat pesisir masih sering menggunakan metode long line tanpa keranjang jaring dalam budidaya rumput laut. Penggunaan metode long line tanpa keranjang jaring memiliki kelemahan yakni mudahnya serangan predator dalam memakan rumput laut seperti ikan baronang (Sigananus) sp., penyu hijau (Chelonia midas), bulu babi (Diadema sp)., dan bintang laut (Protoreaster) yang menyebabkan terjadinya luka pada thallus (Failu $d k k$., 2016).

Berdasarkan uraian diatas, sehingga didapatkan solusi yang dapat kita berikan kepada masyarakat pesisir untuk terlepas dari masalah tersebut dengan melakukan penelitian dengan menggunakan metode yang sama yaitu metode ikat untuk dapat melihat pengaruh perbandingan laju pertumbuhan $K$. alvarezii dengan menggunakan media horinet dan media longnet. Adapun perbedaan kedua media tersebut yakni longnet merupakan media budidaya yang terus menerus melakukan goyangan dan terombang ambing dengan gerakan arus dan gelombang sedangkan horinet adalah media kaku dan benar-benar melindungi rumput laut dari serangan hama dan gerakan fisik gelombang, karena sifat alami dari rumput laut yang melekat pada substrat dan tetap pada suatu tempat tidak bergerak atau tidak bergoyang (Kasim, 2019).

Penelitian ini bertujuan untuk mengetahui pengaruh perbandingan laju pertumbuhan spesifik dan pertumbuhan mutlak rumput laut $K$. alvarezii yang dipeliharaan menggunakan media horinet dan longnet.

\section{BAHAN DAN METODE}

Penelitian ini dilaksanakan pada bulan Oktober-Desember 2019, bertempat di perairan pantai Lakeba Kota Bau-Bau, Provinsi Sulawesi Tenggara. Lokasi Pemeliharaan rumput laut terdiri atas 2 titik, dimana titik 1 berada pada titik koordinat $05^{\circ}$ 
Media Akuatika : Jurnal Ilmiah Jurusan Budidaya Perairan. 2021. 6(1): 19-30.

29' 16,64" LS - $122^{\circ} 33^{\prime} 44,37^{\prime \prime}$ BT dan titik 2 pada titik koordinat $05^{\circ} 29^{\prime} 16,48^{\prime \prime}$ LS$122^{\circ} 33^{\prime} 44,37^{\prime \prime}$ 'BT.

Wadah yang digunakan dalam penelitian ini yaitu menggunakan media longnet dan horinet. Longnet terbuat dari bahan serat atau tali nilon kecil dengan ukuran mata jaring 0,1-3 cm. Longnet memiliki bentuk seperti kantong panjang dengan memiliki ukuran lebar yaitu minimal $40 \mathrm{~cm}$ sebelum dilekukkan dan juga minimal $20 \mathrm{~cm}$ setelah dilekukkan dengan panjang jaring yaitu $500 \mathrm{~cm}$ sehingga membentuk seperti lembaran jaring yang berlapis dan membentuk kantung, serta sisi kiri dan kanan diberi penguat berupa tali (Gambar1). Longnet rumput laut terdiri dari dua komponen utama yaitu jaring pelindung dan penguat samping adalah tali. Jaring pelindung adalah dinding jaring yang dilipat dua dan digantungkan sehingga membentuk kantong yang tergantung. Sedangkan tali yang digunakan sebagai penguat diberikan pelampung sebanyak 6 buah pelampung untuk sisi kanan dan sisi kiri dan ujung jaring tali pengikat di setiap sisi dimasukkan pipa paralon $1 / 2$ inch dengan panjang pipa 10 $\mathrm{cm}$ agar dapat membentuk lekukkan yang menyerupai kantong.

Sedangkan media horinet terdiri dari dua komponen utama antara lain kerangka tulang samping kiri dan samping kanan serta jaring pelindung. Kerangka tulang terdiri dari rakitan pipa paralon atau bahan plastik pipa yang dirangkai persegi empat sama kaki. Jaring pelindung adalah dinding jaring yang membungkus pada kedua kerangka utama. Ukuran mata jaring dinding dapat berkisar antara $0,1 \mathrm{~cm}-4 \mathrm{~cm}$, yang terbuat dari bahan serat atau tali nilon kecil (Gambar 2). Horinet mempunyai bentuk persegi empat panjang sama sisi untuk kerangka utama yang mengapung dipermukaan pada salah satu sisi dan sisi lainnya tenggelam dibawah permukaan air. Pada bagian samping alat tepatnya pada rangka utama alat digantungkan jaring berbentuk kantung persegi empat. Untuk membuat jaring tetap berada diatas permukaan, pada kedua sisi atau pada sisi kerangka utama kiri dan kerangka kanan masing-masing diikatkan pada tali yang terapung dipermukaan air. Bahan kerangka utama kiri dan kanan terbuat dari rangkaian pipa yang dirangkai membentuk segi empat sama sisi, media horinet memiliki ukuran panjang $180 \mathrm{~cm}$, lebar $80 \mathrm{~cm}$ dan tingginya $60 \mathrm{~cm}$

Pemeliharaan rumput laut K.alvarezii yang dilakukan dalam penelitian ini menggunakan metode yang sama yaitu metode ikat tallus menggunakan media horinet dan media longnet, pada masingmasing media tanam rumput laut jenis $K$. alvarezii sebanyak 20 rumpun dengan bobot awal $20 \mathrm{~g}$ setiap rumpun. Lama pemeliharaan selama 42 hari dalam penelitian serta untuk pengontrolan setiap 7 hari sekali. Adapun pengamatan yang perlu dilakukan yaitu dengan melakukan penimbangan pertumbuhan berat bobot rumput laut K.alvarezii, pembersihan dari tanaman seperti lumut dan kotoran yang menempel pada tanaman.

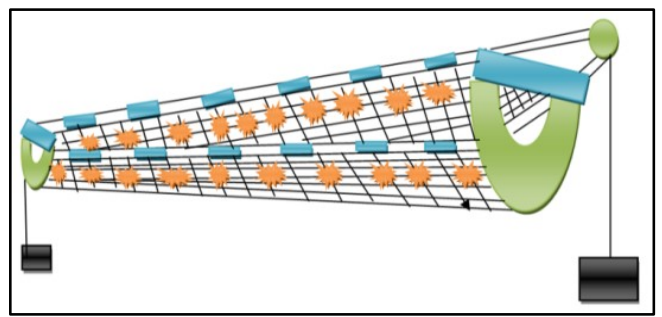

Gambar 2. Median Longnet 


\section{Variabel yang diamati}

\section{Pertumbuhan Mutlak}

Menurut Effendi, (1997) bahwa pertumbuhan mutlak yang digunakan dalam menghitung pertumbuhan rumput laut menggunakan rumus berikut:

\section{$\mathbf{P M}=\mathbf{W t}_{\mathbf{t}} \mathbf{W}_{\mathbf{0}}$}

Dengan: $\mathrm{PM}=$ Laju Pertumbuhan Mutlak Rata-Rata (g), Wt $=$ Berat Rata-Rata Bibit Pada Akhir Penelitian (g), $\mathrm{W}_{0}=$ Berat RataRata Bibit Pada Awal Penelitian (g).

\section{Pertumbuhan Spesifik}

Rumus untuk menghitung laju pertumbuhan spesifik dapat dilihat pada persamaan (2) berdasarkan (Luhan et al., 2010).

$$
\mathbf{L P S}=\left[\left(\frac{w t}{w 0}\right) 1 / t-1\right] \times \mathbf{1 0 0} \%
$$

Dengan: LPS $=$ Laju Pertumbuhan Spesifik harian $(\% /$ hari $), \mathrm{W}_{\mathrm{t}}=$ Bobot rumput laut pada waktu $\mathrm{t}(\mathrm{g}), \mathrm{W}_{\mathrm{o}}$ : Bobot rata-rata bibit pada waktu awal (g)

\section{Analisis Statistik}

Analisis hubungan laju pertumbuhan spesifik rumput laut dengan parameter kualitas air, dianalisis dengan menggunakan uji korelasi pearson menggunakan (SPSS versi 23.) dengan taraf kepercayaan 95\%.

\section{HASIL}

\section{Pertumbuhan Mutlak}

Pertumbuhan mutlak rumput laut $K$. alvarezii secara presentase dari bobot awal yang didapatkan selama proses pemeliharan selama 42 hari, dapat dilihat pada Gambar 3. Nilai rata-rata pertumbuhan mutlak tertinggi pada pemelihara media horinet $74,55 \mathrm{~g}$ dan terendah pada pemeliharaan media longnet $57,5 \mathrm{~g}$ dengan berat bibit awal yang sama sebesar $20 \mathrm{~g}$.

\section{Laju Pertumbuhan Spesifik}

Laju pertumbuhan spesifik (LPS) bobot awal terhadap pertumbuhan $K$. alvarezii selama penelitian 42 hari, diukur dengan menggunakan bibit awal dengan berat yaitu $20 \mathrm{~g}$, dapat dilihat pada Gambar 4.

Nilai rata-rata laju pertumbuhan spesifik untuk media horinet sebesar 3,77\%/hari, sedangkan media longnet sebesar 3,30\%/hari. Pada grafik ini terlihat bahwa laju pertumbuhan rumput laut $K$. alvarezii mengalami penurunan setiap minggunya hingga akhir penelitian, baik itu pada media horinet maupun media longnet.

\section{Kualitas Air}

Hasil pengukuran parameter kualitas air pada lokasi penelitian yaitu terdiri dari kecepatan arus, suhu, salinitas, kecerahan, $\mathrm{pH}$, nitrat, kedalaman dan fosfat (Tabel 1). Hasil uji korelasi pearson menunjukkan bahwa adanya pengaruh antara parameter kualitas air terhadap pertumbuhan rumput laut. Akan tetapi yang berpengaruh secara signifikan dari 8 parameter yaitu didapatkan adalah parameter kecepatan arus.

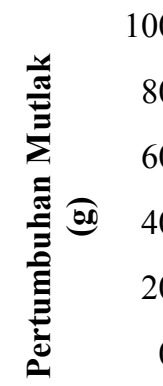

100
80
60
40
20
0
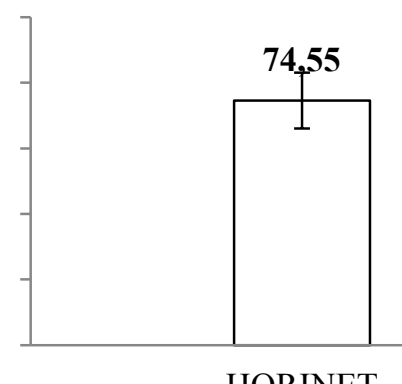

HORINET

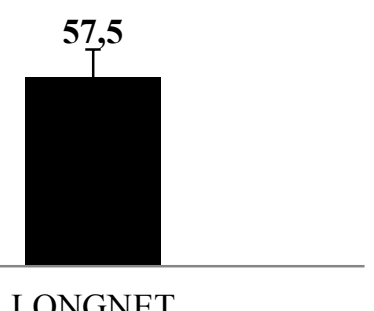

Gambar 3. Histogram Laju Pertumbuhan Mutlak Rumput Laut K. alvarezii yang Dipelihara pada Media Horinet dan Media Longnet 


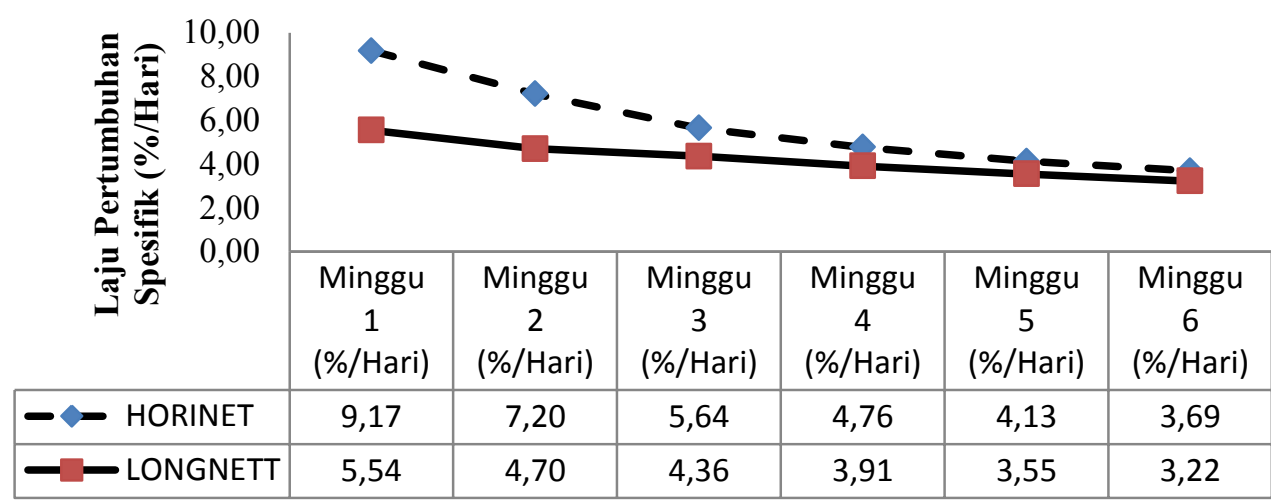

Gambar 4. Histogram Laju Pertumbuhan Spesifik (LPS) Rumput Laut K. alvarezii Selama Penelitian yang Dipelihara pada Media Horinet dan Longnet

Tabel 1. Parameter Kualitas Air selama Penelitian pada Media Horinet dan Longnet

\begin{tabular}{llll}
\hline \multicolumn{1}{c}{ Parameter } & Satuan & \multicolumn{1}{c}{ Kisaran } & \multicolumn{1}{c}{ Pembanding } \\
\hline Kecepatan Arus & $\mathrm{m} / \mathrm{s}$ & $0,10-0,12$ & $0,04-0,15 \mathrm{~m} / \mathrm{s}$ (Candra $d k k ., 2018)$. \\
Suhu & $\mathrm{C}^{0}$ & $28-30$ & $27-30$ (Awalludin $d k k ., 2016)$. \\
Salinitas & $\mathrm{ppt}$ & $32-34$ & $29-34$ (Ghufran \& Kordi,2010) \\
Kecerahan & $\%$ & 100 & $100 \%$ (Risnawati $d k k, 2018)$. \\
$\mathrm{Ph}$ & $\mathrm{ppm}$ & $7,2-7,6$ & $7-8,5$ (SNI, 2010). \\
Nitrat $\left(\mathrm{No}_{3}\right)$ & $\mathrm{mg} / \mathrm{L}$ & $0,002-0,009$ & $0,001-0,012$ (Railkin, 2004). \\
Posfat $\left(\mathrm{Po}_{4}\right)$ & $\mathrm{mg} / \mathrm{L}$ & $0,002-0,004$ & $0,051-1.00 \mathrm{mg} / 1($ Poncomulyo $d k k, 2006)$ \\
Kedalaman & $\mathrm{m}$ & $3-5$ & $5-10$ (Kangkan, 2006). \\
\hline
\end{tabular}

\section{PEMBAHASAN}

Berdasarkan hasil pengamatan laju pertumbuhan spesifik rumput laut $K$. alvarezii yang dipelihara dengan menggunakan metode yang sama yaitu metode ikat dengan menggunakan media yang berbeda yaitu horinet dan longnet, menunjukkan bahwa pertumbuhan rumput laut selama pemeliharaan berlangsung masih dikategorikan baik dengan nilai rata-rata untuk media horinet berkisar 3,69\%/hari dan longnet berkisar $3,22 \%$ /hari, dari kedua media tersebut dapat dikatakan laju pertumbuhan spesifik tertinggi dibandingkan dengan penelitian yang didapatkan oleh Bolqiah dkk., (2018) yaitu 1,34\% untuk stasium 1 dan 1,57\% untuk stasium 2 yang dilakukan pada perairan kelurahan lakorua, kabupaten buton tengah. Sedangkan penelitian yang dilakukan Hurtado et al., (2008) laju pertumbuhan yang didapatkan 1,14\%/hari, Sementara untuk laju pertumbuhan tertinggi juga diperoleh penelitian Munoz et al., (2004) sebesar 2,0$8,1 \%$ /hari, dan Thirumaran \& Anantharaman (2009), sebesar 2,33-5,22\%/hari. Menurut Nursyahran dan Reskiati (2013), bahwa pada minggu pertama adalah fase terbentuknya pertumbuhan vegetatif, dimana tumbuhan melaksanakan perkembangan selsel jaringan dewasa sehingga didapatkan perkembangan berat terus menjadi lebih besar. Menurut Mutalib \& Rahman (2018), menurunnya laju pertumbuhan spesifik dikarenakan rendahnya tingkat pertumbuhan yaitu adanya penambahan bobot thallus yang lebih rendah seiring dengan pertambahan usia pemeliharaan rumput laut yang menyebabkan terjadinya persaingan dalam memperoleh unsur hara dan penyerapan sinar matahari dalam proses fotosintesis, sehingga laju pertumbuhan rumput laut semakin menurun. Menurut Gultom $d k k$., (2019) menyatakan bahwa semakin padat rumput laut yang dipelihara maka semakin rendah pula pertumbuhan. Sedangkan menurut Amin $d k k$., (2005), penurunan laju 
pertumbuhan spesifik diduga akibat terjadinya kejenuhan pembelahan sel, rumput laut yang telah mengalami proses adaptasi kemudian mengalami fase pertumbuhan sel yang menyebabkan pertumbuhan yang lambat. Menurut Gultom $d k k$., (2019) yang menyatakan bahwa semakin besar bobot pertumbuhan rumput laut semakin padat densitas tanaman karena tumbuhnya tunas-tunas baru dan cabang yang membesar menyebabkan ruang gerak semakin sempit, persaingan antara tanaman untuk memperoleh makanan (nutrisi) semakin besar serta mendapatkan cahaya matahari dalam proses fotosintesis semakin ketat.

Laju pertumbuhan spesifik dipengaruhi oleh pertumbuhan pada thallus rumput laut. Pada grafik menunjukkan bahwa grafiknya terlihat sedikit curam atau dapat dikatakan bahwa tiap minggunya mengalami penurunan baik pada pemeliharaan media horinet maupun longnet. Hal ini sesuai dengan pernyataan Abdan dkk., (2013), menyatakan salah satu yang mempengaruhi pertumbuhan adalah jumlah thallus. Menurut Yusnaini $d k k$., (2000) bahwa penurunan laju pertumbuhan spesifik diduga akibat cepatnya terjadi kejenuhan pembelahan sel. Poncomulyo $d k k$., (2006) menyatakan bahwa laju pertumbuhan rumput laut yang dianggap cukup menguntungkan yaitu $3 \%$ pertambahan berat/hari. Menurut Syahlun $d k k$. , (2013) bahwa suatu kegiatan budidaya rumput laut dikategorikan baik jika laju pertumbuhan harian berkisar 2\%. Sedangkan menurut Safia $d k k$., (2019) bahwa laju pertumbuhan rumput laut yang dianggap cukup menguntungkan adalah $3 \%$ pertambahan berat per hari atau $21 \%$ per minggu.

Tingkat pertumbuhan rumput laut $K$. alvarezii selama bulan november-desember sangat lambat pertumbuhan dimana pada bulan tersebut tidak terlalu baik untuk dilakukan budidaya karna pada bulan tersebut cuaca di perairan pantai lakeba tidak memungkinkan untuk kegiatan budidaya rumput laut karena berada pada musim barat dan ombak yang tinggi. Hal ini sesuai dengan pernyataan Paula \& Perairan (2003), bahwa pengaruh musiman terhadap pertumbuhan rumput laut tertinggi diperoleh pada musim panas (januari-mei) sedangkan pertumbuhan terendah diperoleh pada musim hujan (juni-desember). Menurut Hayashi et al., (2007) mengatakan bahwa pada bulan februari-mey lebih tinggi laju pertumbuhan spesifik rumput laut dibandingkan dengan bulan juli-desember pertumbuhannya menurun. Menurut Msuya \& Salum (2007), pertumbuhan rumput laut memberikan respon yang berbeda terhadap musim, biasanya $K$. alvarezii tumbuh baik pada musim kemarau dan lambat pertumbuhannya pada musim hujan. Pertumbuhan rumput laut yang lambat pada musim hujan disebabkan karena kisaran salinitas yang fluktuatif.

\section{Pertumbuhan Mutlak}

Pertumbuhan mutlak adalah hasil bobot pertumbuhan dari berat akhir dikurangi dengan berat awal rumput laut. Pertumbuhan mutlak nilai rata-rata yang terlihat pada grafik rumput laut $K$. alvarezii diperoleh pada media horinet sebesar 74,55 $\mathrm{g}$ sedangkan pada pemeliharaan media longnet sebesar $57,5 \mathrm{~g}$ dimana jauh lebih rendah dibandingkan penelitian yang diperoleh oleh Yusup $d k k$., (2017) yaitu $28,4 \mathrm{~g}$ dengan pemeliharaan menggunakan rakit jaring apung yang bertempat di desa tanjung tiram, kecamatan moramo utara, kabupaten konawe selatan, provinsi sulawesi tenggara dan terendah juga didapatkan oleh Faisal $d k k$., (2011) sebesar 41,48 g - 49,63 g dan tertinggi didapatkan oleh Hamid (2009) sebesar 4,45 - 7,30 g, dan Masyahoro \& Mappiratu (2010) sebesar 6,16 - 10,68 g. Dalam hal ini rumput laut yang kita pelihara dengan dua metode yang berbeda dapat tumbuh dengan kondisi yang baik, hal ini disebabkan karena dari segi bibit yang kita gunakan masih sangat bagus dan segar. Bibit yang kami gunakan dalam pemeliharaan ini yaitu dengan berat awal sebesar $20 \mathrm{~g}$. Bibit awal yang kecil lebih cenderung lebih cepat pertumbuhannya, hal ini disebabkan karena faktor dalam memperoleh nutrien dapat secara merata karena tidak adanya persaingan thallus untuk memperoleh nutrien. Hal ini sesuai dengan pernyataan Tiwa $d k k$., (2013) bahwa laju pertumbuhan 
rumput laut sangat dipengaruhi oleh berat bibit awal rumput laut yang akan dibudidayakan, dimana bibit awalnya kecil memberikan hasil pertumbuhan yang lebih cepat karena tidak terjadi persaingan antara talus dalam memperoleh nutrien. Indriani \& Sumiarsih (2003), menyatakan bahwa pemenuhan unsur hara sangat mempengaruhi pertumbuhan. Ruang gerak yang cukup untuk rumput laut menyebabkan terjadinya peningkatan laju pertumbuhan karena suplai nutrisi berlangsung optimal. Bibit yang kecil mempunyai proses regenerasi yang lebih cepat dibandingkan yang memiliki bobot yang besar.

Grafik pertumbuhan mutlak dapat dilihat bahwa setiap minggu pemeliharaan rumput laut $K$. alvarezii mengalami kenaikan, hal ini disebabkan oleh didukungnya suatu penggunaan media dalam budidaya rumput laut yaitu horinet dan longnet. Pada media horinet memiliki bentuk kaku dan terkesan benar-benar melindungi rumput laut dari serangan hama, aktivitas manusia dan gerakan fisik gelombang karena sifat alami dari rumput laut yang melekat pada substrat sedangkan longnet dimana alat budidayanya terus menerus melakukan goyangan dan terombang ambing dengan gerakan arus sehingga rumput laut yang dipelihara menjadi patah serta rentan terhadap ikan herbivora dan adanya lumut yang menempel pada thallus maupun jaring longnet sehingga menyebabkan sangat sulit menerima sinar matahari untuk berfotosintesis. Hal ini didukung oleh pernyataan Kasim \& Mustafa., (2017) pemeliharaan budidaya rumput laut dengan menggunakan kurungan lebih baik yaitu misalnya menggunakan jaring apung yang dimana budidayanya sangat efektif untuk budidaya rumput laut. Menurut Kasim dan Asnani (2012), rumput laut yang terkurung memberikan proteksi baik dari serangan ikan herbivora yang senang dengan pucuk rumput laut. Sedangkan Menurut Wijayanto $d k k$., (2011) mengatakan bahwa penanaman menggunakan metode rakit apung lebih efektif dibandingkan dengan menggunakan metode longline karena pada umumnya metode rakit apung lebih baik karena intensitas cahaya yang cukup memadai dan pergerakan air untuk pertumbuhan rumput laut. Menurut Parenrengi $d k k$., (2012) bahwa arus yang membawa suatu partikel zat padat akan menempel pada thallus dan mengganggu proses fotosintesis. Serdiati \& Widiastuti., (2010) menyatakan bahwa peningkatan fotosintesis dapat meningkatkan kemampuan alga laut untuk memperoleh unsur hara atau nutrisi.

\section{Kualitas Air}

Suhu yang diperoleh dalam penelitian berkisar $28-30^{\circ} \mathrm{C}$, hal ini dapat dikatakan suhu yang diperoleh selama proses pemeliharaan sangat layak untuk pertumbuhan dan perkembangan rumput laut $K$. alvarezii. Apabila suhu yang didapatkan diatas $32^{\circ} \mathrm{C}$ menyebabkan aktivitas cahaya terhambat. Menurut Kasim \& Mustafa (2017), suhu yang baik untuk pertumbuhan $K$. alvarezii berkisar $25-31^{\circ} \mathrm{C}$. Menurut Ruslaini (2016), kisaran suhu yang diperoleh selama penelitian $25-30^{\circ} \mathrm{C}$ sangat baik untuk budidaya rumput laut. Menurut Hung $d k k$., (2009) suhu optimal bagi pertumbuhan rumput laut $K$. alvarezii $25-30^{\circ} \mathrm{C}$. Menurut Gultom $d k k$., (2019) suhu perairan sangat spesifik mempengaruhi pertumbuhan rumput laut. Suhu perairan yang besar menimbulkan kematian pada rumput laut. Hal tersebut bisa terjadi dalam proses fotosintesis, kerusakan enzim serta membran yang bersifat labil. Sebaliknya pada suhu yang rendah membran protein serta lemak mengalami kehancuran dan membentuk kristal serta hal tersebut mempengaruhi kehidupan rumput laut.

Salinitas yang didapatkan selama penelitian berkisar 34-35 ppt, dimana masih dalam keadaan layak untuk dilakukan budidaya rumput laut. Rumput laut akan mengalami pertumbuhan lambat, apabila salinitas yang didapatkan rendah jauh dibawah batas toleransi maka rumput laut akan berwarna pucat, gampang patah dan lunak sehingga akhirnya membusuk tidak tumbuh normal dan akan mati, untuk salinitas tinggi menyebabkan thallusnya pucat kekuning-kuningan menjadikan rumput laut tidak baik tumbuhnya (Asni, 2015). Menurut Ruslaini (2016), salinitas dapat mempengaruhi kesuburan rumput laut selama masa pemeliharaan, adapun salinitas yang diperoleh dalam penelitian berkisar 
antara 30-34 ppt dan berada pada salinitas yang dapat ditolerir oleh rumput laut (Eucheuma cottonii). Tisera \& Naguit (2009), yaitu rumput laut membutuhkan salinitas penuh 32-35 ppt untuk memperoleh pertumbuhan optimal.

Kecepatan arus didapatkan selama proses pemeliharaan $0,10-0,12 \mathrm{~cm} /$ detik, dimana keadaan tersebut sangat tidak layak untuk dilakukan budidaya rumput laut karena kecepatan arus yang didapatkan sangat lambat. Adapun penelitian yang didapatkan oleh Risnawati dkk., (2008) yang penelitiannya dilakukan di pantai lakeba, kota bau-bau, sulawesi tenggara didapatkan berkisar 0,05-0,08 $\mathrm{cm} /$ detik, kecepatan arus yang diperoleh juga sangat rendah. Sedangkan penelitian yang didapatkan Pratama dkk., (2020) sebesar $0,03 \mathrm{~m} / \mathrm{dtk}$ pada saat kondisi menuju surut terendah dan $0,14 \mathrm{~m} / \mathrm{dtk}$ pada saat kondisi menuju pasang tertinggi, hal ini menunjukkan kondisi kecepatan arus maksimum antara jam 08:00 WIB sampai 09.00 WIB (pagi hari). Sebagaimana yang dikemukakan oleh Rombe dkk., (2013) bahwa kecepatan arus yang lambat menyebabkan rumput laut tumbuh subur sehingga mendominasi pengambilan cahaya, ruang dan makanan dibandingkan rumput laut yang dibudidaya serta cahaya matahari akan banyak diserap makroalga, kecepatan arus tinggi menyebabkan terjadinya patahan bagian thallus akibat kecepatan arus yang terlalu tinggi. Menurut Mason (1993), yaitu pengelompokkan perairan yang berarus sangat cepat $(>1 \mathrm{~cm} / \mathrm{dtk})$, cepat $(0,5-1$ $\mathrm{cm} / \mathrm{dtk})$, sedang $(0,25-0,5 \mathrm{~cm} / \mathrm{dtk})$, lambat $(0,1-0,2 \mathrm{~cm} / \mathrm{dtk})$ dan sangat lambat $(<0,1$ $\mathrm{cm} / \mathrm{dtk})$.

Kisaran $\mathrm{pH}$ yang didapatkan selama proses pemeliharaan relatif stabil dan berada pada kisaran adaptasi bagi rumput laut sebesar 7,2-7,7. Menurut Kurniawan $d k k$., (2020) $\mathrm{pH}$ merupakan salah satu parameter pendukung untuk pertumbuhan rumput laut, dimana kisarannya yaitu 7,7-8,2. Menurut Ruslaini dan Wa Iba (2011), pH kurang dari 4.0 sebagian tumbuhan air mati, karena tidak dapat bertoleransi pada $\mathrm{pH}$ yang rendah. Menurut Odum (1993), kemampuan menyangga air laut yang sangat besar mencegah perubahan $\mathrm{pH}$. Perubahan $\mathrm{pH}$ sedikit akan menyebabkan terganggunya sistem penyangga, sehingga menimbulkan suatu perubahan dan ketidakseimbangan kadar CO2 yang membahayakan biota laut.

Kondisi kecerahan dalam lokasi penelitian sangat layak untuk pertumbuhan rumput laut. Hal ini sesuai dengan pernyataan Hayashi $d k k$., (2007) kecerahan perairan lokasi yang cocok untuk budidaya rumput laut $>2 \mathrm{~m}$. Perairan yang semakin cerah berarti partikel lumpur yang terdapat dalam kolam air sedikit, sehingga cahaya akan menunjang fotosintesis dalam proses metabolisme yang dapat merangsang rumput laut menyerap unsur hara yang lebih banyak (Rachmawati \& Abdillah, 2019). Menurut Risnawati $d k k$., (2018) bahwa tingkat kecerahan perairan yaitu $80-100 \%$ sangat baik untuk budidaya rumput laut.

Pengukuran kedalaman selama proses pemeliharan pada pasang tertinggi berkisar 5,3 $\mathrm{m}$ sedangkan pada surut terendah berkisar 3,6 m, kedalaman perairan ini dikategorikan baik bagi pertumbuhan rumput laut. Menurut Mustafa $d k k$., (2017) apabila kedalaman perairannya dangkal dengan substrat dasarnya berlumpur sangat besar kemungkinannya terjadi kekeruhan perairan melalui pengadukan gelombang dan arus sampai ke dasar perairan. Sedangkan menurut Poncomulyo $d k k$., (2006) kisaran kedalaman antara 4-17m. Menurut Khan \& Satam (2003) kisaran kedalaman minimal 30 $\mathrm{cm}-60 \mathrm{~cm}$, ketika lokasi budidaya mengalami surut maka rumput laut masih dapat tumbuh dengan baik sehingga penyerapan nutrisi dapat berlangsung dan rumput laut tidak rusak secara langsung oleh terpaparnya sinarnya matahari.

Pengukuran nitrat yang didapatkan selama proses pemeliharaan berlangsung berkisar antara 0,002-0,009 $\mathrm{mg} / \mathrm{L}$. Sedangkan hasil penelitian yang didapatkan oleh Yusup dkk., (2017) yaitu berkisar $0,0108 \mathrm{mg} / \mathrm{L}-0,215 \mathrm{mg} / \mathrm{L}$ dan kisaran ini juga masih sangat rendah untuk pertumbuhan rumput laut $K$. alvarezi. Menurut Utojo dkk., (2007) kadar nitrat yang ideal untuk rumput laut berkisar antara 0,0057-0,00185 g/l. Menurut Rujiman $d k k$. ,(2013) bahwa konsentrasi nitrat perairan yang baik untuk pertumbuhan rumput laut adalah 0,0071-0,0169 mg/l. Sedangkan 
menurut Railkin (2004), kisaran nitrat 0,001-0,012 $\mathrm{mg} / \mathrm{l}$, nitrat merupakan salah satu faktor pendukung pertumbuhan rumput laut, karna semakin besar konsentrasi nitrat maka semakin bagus perkembangan rumput laut serta semakin besar kandungan karaginan yang diperoleh.

Kisaran fosfat yang diperoleh selama penelitian berkisar 0,002-0,004 mg/l. Hal ini sesuai dengan pernyataan Poncomulyo $d k k$., (2006) kisaran fosfat yang optimum untuk pertumbuhan rumput laut adalah 0,051-1,00 mg/l. Sedangkan menurut Kepmen No.51/MENKLH (2004), bahwa kisaran nilai fosfat untuk budidaya rumput laut adalah 0,1-0,2 tergolong sangat baik, kemudian $0,02-<0,1$ juga masih dikatakan tergolong baik sedangkan yang $<0,02$ sudah dikatakan kurang baik. Menurut Radulovich $d k k$., (2015) kisaran fosfat optimal untuk pertumbuhan rumput laut 0.05-1.00 ppm dan apabila salah satu unsur hara tidak tersedia akan menyebabkan pertumbuhan, perkembangan serta produksi rumput laut terhambat.

\section{KESIMPULAN}

Laju pertumbuhan spesifik rumput laut $K$. alvarezii yang diperoleh untuk media horinet 3,77\%/hari dan longnet sebesar $3,30 \% /$ hari. Laju pertumbuhan mutlak nilai rata-rata diperoleh untuk media horinet $74,55 \mathrm{~g}$ sedangkan pada media longnet diperoleh dari $57,5 \mathrm{~g}$, dengan berat bibit awal $20 \mathrm{~g}$.

\section{REFERENSI}

Abdan., Rahman, A., Ruslaini. 2013. Pengaruh Jarak Tanam Terhadap Pertumbuhan dan Kandungan Karaginan Rumput Laut (Eucheuma spinosum) Menggunakan Metode Longline. Mina Laut Indonesia. Vol 3(12): 113-123.

Amin, T, P., Rumanyar., Femmi, N, F., Kemue, D., Suwitra, I, K. 2005. Kajian Budidaya Rumput Laut (Eucheuma cottonii) Dengan Sistem dan Musim Tanam Yang Berbeda di Kabupaten Bangkep Sulawesi Tengah. Balai Pengkajian Teknologi Pertanian Sulawesi Tengah. 55 Hal.
Asni, A. 2015. Analisis Produksi Rumput Laut Kappaphycus alvarezii berdasarkan musim dan jarak lokasi budidaya di Perairan Kabupaten Bantaeng. Jurnal Akuatik 2: 140153.

Bolqiah, S., Kasim, M., Afu, L, O, A. 2018. Hubungan Faktor Oseanografi Terhadap Pertumbuhan Rumput Laut Dengan Metode Rakit Jaring Apung Di Perairan Lakorua Kecamatan Mawasangka Tengah Kabupaten Buton Tengah. Jurnal Sapa Laut. Vol 3(1): 25-36.

Failu, I., Supriyono, E., Hari, S, S. 2016. Peningkatan kualitas karagenan rumput Laut Kappaphycus alvarezii dengan metode budidaya keranjang jaring. Jurnal Akuakultur Indonesia. Vol 15 (2): 124-131.

Faisal, L, O., Patadjai, R, S., Yusnaini. 2011. Pertumbuhan Rumput Laut Kappaphycus alvarezii dan Ikan Baronang Yang diBudidayakan Bersama Dengan Keramba Tancap.

Gultom, R, C., Diirgayusa, I, G, N, P., Puspitha, N, L, P, R. 2019. Perbandingan Laju Pertumbuhan Rumput Laut (Eucheuma cottonii) Dengan Menggunakan Sistem Budidaya Ko-kultur dan Monokultur di Perairan Pantai Geger, Nusa Dua, Bali. JMRT, Vol 2 (1): 8-16.

Hamid, A. 2009. Pengaruh Berat Bibit Awal Dengan Metode Apung Terhadap Persentase Pertumbuhan Harian Rumput Laut. Skripsi. Jurusan Biologi. Fakultas Sains dan Teknologi. UIN. Malang.

Hayashi, L., de Peula, E, J., Chow, F. 2007. Growth Rate and Carrageenan Analysis, In Four Strains Of Kappaphycus alvarezii (Rhodophyta, Gigatinales) Farmed In The Subtropical Waters Of Sao Paulo State, Brazil. Journal Of Applied Phycology. 19(5):393-399.

Hung, L, D., Hori, K., Nang, H, Q., Kha, $\mathrm{T}$ and Hoa., L, T. 2009. Seasonal Changes In Growth Rate, 117 Carrageenan Yield and Lectin Content In The Red Alga Kappaphycus 
alvarezii Cultivation In Camranh Bay, Vietnam. Journal Of Applied Physiology 21: 265-272.

Hurtado, A. Q., A. T. Critchley, A. Trespoey and G. Bleicher-L'honneur. 2008. Growth and Carrageenan Quality of Kappaphycus striatum var. Sacol Grown at Different Stocking Densities, Duration of Culture and Depth. J. Appl. Phycol, 20: 551-555.

Indriani, H dan Suminarsih, E. 2001. Budidaya, Pengolahan dan Pemasaran Rumput Laut. Penebar Swadaya. Jakarta, 87 hal.

Kasim, M and Mustafa, A. 2017. Comparison growth of Kappaphycus alvarezii (Rhodophyta, Solieriaceae) cultivation in floating cage and longline in Indonesia. Aquaculture Report 6 (2017): 49-55.

Kasim, M dan Asnani. 2012. Penentuan Musim Reproduksi Generatif dan Preferensi Perlekatan Spora Rumput Laut (Eucheuma cottonii). Fakultas Perikanan dan Ilmu Kelautan, Universitas Halu oleo. 17 (4): 209$216 \mathrm{Hal}$.

Kasim, M. 2019.Buku Panduan ALGANET Inovasi Alat Budidaya Rumput Laut.Lembaga Penelitian dan Pengabdian Kepada Masyarakat. Universitas Halu Oleo, Kendari.

Kasim, M., Mustafa, A., Munier, T. 2016. The growth rate of seaweed (Eucheuma denticulatum) cultivated in longline and floating cages. AACL Bioflux. 9(2): 291-299.

KEPMEN KLH. 2004. Keputusan Menteri Negara Lingkungan Hidup Nomor 51 Tahun 2004 Tentang Baku Mutu Air Laut. Kementerian Negara Lingkungan Hidup.

Khan, S, I and S. B. Satam. 2003. Seaweed Mariculture. Scope and Potential In India. Aquaculture Asia. Vol 8(4): 2629.

Kurniawan, P, M., Kreckhoff, R, L., Ngangi, E, L, A., Wagey, B, T. 2020. Pertumbuhan Rumput Laut Kappaphycus alvarezii (Doty) yang Direndam Dalam Ekstrak Daun Ketapang Terminalia Catappa L,
Dengan Frekuensi Berbeda. Budidaya Perairan. Vol 8(2): 1-13.

Luhan MRJ and Sollesta. 2010. Growing the reproduktive cells (carpospores) of the seaweed, kappaphycus striatum in the laboratory until outplaning in the field an naturation to tetrasporophte. J Appl Phycol 22:579-585

Mason, C, F. 1993. Biology Of Freshwater Pollution. New York: Longman Scientific and Technical.

Masyahoro dan Mappiratu.2010. Respon Pertumbuhan Pada Berbagai Kedalaman Bibit dan Umur Panen Rumput Laut Eucheuma Cottonii Di Perairan Teluk Palu. Media Litbang Sulteng.Vol 3(2) : $104-111$. ISSN: $1979-5971$.

Msuya, F, E and D, Salum. 2007. The Effect Of Cultivation, Duration, Seasonality and Nutrient Concentration Of The Growth Rate and Biomass Yield Of The Seaweeds. Kappaphycus alvarezii and Eucheuma denticulatum In Zanzibar, Tanzania. MARG-I Final Report Submitted To The Wastern Indian Ocean Marine Sciences Association (WIOMSA), 23 $\mathrm{pp}$.

Munoz, J., Y. Freile-Pelegrin and D. Robledo. 2004. Mar Culture of Kappaphycus alvarezii (Rhodophyta, Solieriaceae) Color Strains in Tropical Waters of Yucatan, Mexico. Aquaculture, 239: 161177.

Mustafa, A., Tarunamulia., Hasnawi, Radiarta, N. 2017. Karakteristik, Kesesuaian dan Daya Dukung Perairan Untuk Budidaya Rumput Laut Di Kabupaten Kepulauan Sangihe, Sulawesi Utara. Riset Akuakultur. Vol 12(2): 187-196.

Mutalib, Y. dan Rahman, S, A. 2018. Pertumbuhan dan Kandungan Karaginan Rumput Laut Kappaphycus alvarezii Pada Dosis Mikroorganisme Lokal (MOL) Buah Maja. Journal of Blue Oceanic. Vol 2(1): 1-8.

Nugroho, E dan Kusnandar, E. 2015. Agribisnis Rumput Laut. Swadaya Group. Jakarta. Hal 19. 
Media Akuatika : Jurnal Ilmiah Jurusan Budidaya Perairan. 2021. 6(1): 19-30.

Nursyahran dan Reskiati. 2013. Peningkatan Laju Pertumbuhan Thallus Rumput Laut (Kappaphycus alvarezii) Yang Direndam Air Beras Dengan Konsentrasi Yang Berbeda. Vol 4(2):13-18 hal.

Odum, E, P. 1993. Dasar-Dasar Ekologi. Edisi Ketiga. Yogyakarta. Gajah Mada University Press.

Parenrengi, A., Rachmansyah., Suryati, E. 2012. Budidaya Rumput Laut Penghasil Karaginan (Karaginofit). Balai Penelitian dan Pengembangan Budidaya Air Payau. Maros. Hal: 54.

Paula, E, J and Pereira R, T, L. 2003. Factors Affecting Growth Rates Of (Doty) Doty Ex P. Silva Tropical Waters Of Sao Paulo State, Brazil. Proceeding On International Seaweed Symposium. 17: 381-388.

Poncomulyo, T., Maryanih., Kristiani, L. 2006. Budidaya dan Pengolahan Rumput Laut. Jakarta: Agromedia Pustaka. Hal 14, 15 dan 35.

Pratama, M, A, P,P., Barus, B, S., Putri, W, A, E. 2020. Perubahan Garis di Pantai Muara Banyuasin Kaitannya Dengan Sedimentasi. Jurnal Ilmu dan Teknologi Kelautan Tropis. Vol 12(1): 107-118.

Rachmawati, S dan Abdillah, A, A. 2019. Studi Pertumbuhan Bibit Rumput Laut (Kappaphycus alvarezii) Hasil Kultur Jaringan Dengan Metode Longline Berbingkai Di Balai Besar Perikanan Budidaya Laut Lampung. Jurnal Perikanan Pantura. Vol 2(10: 19.

Radulovich, R., Umanzor, S., Cabrera, R., Mata, R. 2015. Tropical seaweeds for human food, their cultivation and its effect on biodiversity enrichment. Aquaculture 436: 40-46

Railkin, A, I, 2004. Marine Biofouling: Colonization Processes \& Defenses. Lavoisier, London UK. 12-17 pg.

Risnawati., Kasim, M., Haslianti. 2018. Studi Kualitas Air Kaitannya dengan Pertumbuhan Rumput Laut (Kappaphycus alvarezii) Pada Rakit Jaring Apung Di Perairan Pantai Lakeba Kota Bau-Bau Sulawesi
Tenggara. Jurnal Sumber Daya Perairan. Vol 4(2):155-164.

Rombe, K, H., Yasir, I., Amran, M, A. 2013. Komposisi jenis laju pertumbuhan makroalga fouling pada media budidaya ganggang laut di perairan kabupaten bantaeng. jurusan ilmu kelautan. Fakultas Ilmu Kelautan dan Perikanan. Universitas Hasanudin: Makassar. hal 9-12.

Rujiman, L, M., Aslan, L, M., Sabilu, K. 2013. Pengaruh Jarak Tali Gantung dan Jarak Tanam Yang Berbeda Terhadap Pertumbuhan Rumput Laut (Kappaphycus alvarezii) Strain Hijau Melalui Seleksi Klon Dengan Menggunakan Metode Vertikultur (Periode I-III). Mina Laut Indonesia. Vol 3(12):22-35.

Ruslaini dan Wa Iba. 2011. Studi Kondisi Kualitas Air Budidaya Rumput Laut (Gracilaria verrucosa) pada Tambak Tanah Sulfat Masam (Studi Kasus di Kecamatan Moramo, Kabupaten Konawe Selatan Provinsi Sulawesi Tenggara). Jurnal Aqua Hayati. Vol 7(3): 189-195.

Ruslaini. 2016. Kajian Kualitas Air Terhadap Pertumbuhan Rumput Laut (Gracilaria verrucosa) di Tambak Dengan Metode Vertikultur. Jurnal Ilmu Perikanan Octopus. Vol 5(2): 522-527.

Safia, W., Budiyanti., Musyrif. 2019. Pertumbuhan dan Karaginan Rumput Laut (Eucheuma cottoni) Dengan Menggunakan Pengembangan Metode Rakit Gantung Pada Kedalaman Berbeda. Sinergitas Multidisiplin Ilmu Pengetahuan dan Teknologi. Vol 2(1): 101-108.

Saputra, R., Patadjai., R, S., dan Balubi, A, M. 2013. Analisis Pertumbuhan dan Kadar Karaginan Rumput Laut Kappaphycus alvarezii pada Lokasi Berbeda di Perairan Sekitar Penambangan Kecamatan Lasolo Kabupaten Konawe Utara. Jurnal Mina Laut Indonesia. Vol 3(12):5567.

Serdiati, N dan Widiastuti, I, M. 2010. Pertumbuhan dan Produksi Rumput Laut Eucheuma cottonii Pada 
Media Akuatika : Jurnal Ilmiah Jurusan Budidaya Perairan. 2021. 6(1): 19-30.

Kedalaman Penanaman Yang Berbeda. Jurnal Media Litbang Sulteng. Vol 3(1): 21-26.

Soenardjo, N. 2011. Aplikasi Budidaya Rumput Laut Eucheuma cottonii (Weber van Bosse) dengan Metode Jaring Lepas Dasar (Net Bag) Model Cidaun. Jurnal Buletin Oseanografi Marina, 1(1): 36-44.

Susanto, A. B. 2005. Metode Lepas Dasar Dengan Model Cidaun Pada Budidaya Eucheuma spinosum (Linnaeus) Agardh. Jurnal Ilmu Kelautan. Vol 10(3):158-164.

Syahlun., Rahman, A., Ruslaini. 2013. Uji Pertumbuhan Rumput Laut (Kappaphycus alvarezii) Strain Coklat Dengan Metode Vertikultur. Mina Laut Indonesia. Vol 1(1): 122-132.

Thirumaran, G and Anatharaman, P. 2009. Daily Growth Rate of Field Farming Seaweed Kappaphycus alvarezii (Doty) Doty ex P. Silva in Vellar Estuary. World Journal of Fish and Marine Sciences 1 (3): 144-153.

Tisera, W, L and Naguit, M, R, A. 2009. Ice-Ice Disease Occurrence In Seaweed Farms In Bais Bay, Negros Oriental and Zamboanga Del Norte. The Threshold IV: 1-16.

Tiwa, R., Mondoringin, L., Salindeho, I. 2013. Pertumbuhan Rumput Laut Kappaphycus alvarezii Pada Perbedaan Kedalaman Dan Berat Awal Di Perairan Talengen Kabupaten Kepulauan Sangihe. Budidaya Perairan. Vol 1(3): 63-68.

Utojo, A. Mansyur, B. Pantjara, A, M., Pirzan., Hasnawati. 2007. Kondisi Lingkungan Perairan Teluk Mallasoro yang Layak untuk Lokasi Pengembangan Budidaya Rumput Laut (Eucheuma Sp.). Jurnal Akuakultur. Vol 2(2):243-255.

Wijayanto, T., Hendri, M., Aryawati, R. 2011. Studi Pertumbuhan Rumput Laut Eucheuma cottonii Dengan Berbagai Metode Penanaman Yang Berbeda di Perairan Kalianda, Lampung Selatan. Maspari Journal. Vol 3(1): 51-57.

Wiratmaja, I.G., Kusuma, I, G, B,W., Winaya, I, N, S. 2011. Pembuatan
Etanol Generasi Kedua Dengan Memanfaatkan Limbah Rumput Laut Eucheuma Cottonii Sebagai Bahan Baku. Jurnal Ilmiah Teknik Mesin Cakra. Vol 5(1):75-84.

Yusnaini, Ramli, U.K. Pangerang. 2000. Budidaya Intensif Teripang Pasir Holothuria scabra dengan Menggunakan Alga Eucheuma cottonii Sebagai Shelter. Laporan Hasil Penelitian Lembaga Penelitian. Universitas Haluoleo. Kendari.

Yusup, S., Kasim, M., Balubi, A, M. 2017. Pengaruh Bobot Awal Yang Berbeda Terhadap Pertumbuhan Dan Kandungan Karaginan Rumput Laut Kappaphycus alvarezii Yang Terserang Epifit Dalam Rakit Jaring Apung. Jurnal Media Akuatik. Vol 2(4): 509-518. 